\title{
Editorial Introduction: India and Travel Narratives
}

Travelogues belong to an interdisciplinary realm where discourses like literature, history, politics, anthropology, geography, economics, ethnography and even linguistics cross one another thus turning it into a proper subject of cultural/intercultural studies. It can be used as a site for raising questions, not only of ideology but of subjectivity as well, as the travelling subject is as important in a travelogue as the country travelled to. Traditionally an identity-building enterprise, travel writing is particularly interesting, since the persona of the traveller tends to rest on a cluster of oppositional concepts such as home-away, centre-periphery, near-distant, etc. Travel writing is also the art of discovering the magic of ordinary persons, places and things. You can discover magic only if you can look beyond reality to the reality behind everything. The famous travel writers Hugh and Colleen Gantzer believe that seldom travel builds bridges between people and times and civilizations. But that they believe, is what travel is really all about. The urge to travel was built in our genes, driven by the magic of curiosity.

Though earlier not recognized as a canonical subject for writing research papers, in the last three decades, the protean and hybrid genre of travel writing have been accepted as one of the most interesting areas in transnational and cross-cultural research. The deluge of new publications related to this genre proves the enormous possibilities through which travel writing can be studied. The nature of the writing includes several forms, namely letters, diaries, autobiographies or oral records but it is too complex and too varied to be subjected to any neat classification.

Indian travel writing is considered to be the product of the colonial encounter. It proliferated in the nineteenth century and borrowed the genre from English travel writing but with time a great deal else is yet to be discovered. One can trace the elements of travel writing to pre-colonial times as well. Elements of the travelogue exist in the fictional accounts of the digvijayas in the epics, the safarnamas, tirthya-mahatyas or devotional accounts of the pilgrimages undertaken by saints, religious heads and poets, and in the lyrical reminiscences of a homesick lover like the Yaksha in Kalidasa's Meghdoot. Questions are often raised about the specific nature of Indian travel narratives. So when the call for papers for the special issue of this journal was announced, we made it clear that we would like to focus on the travel writings by Indians and thus hide the problems of definition. The travel writing could be within India or the journey undertaken maybe to anywhere in the world and can be written in either English or any regional language. The study can be on individual texts, overviews, and any other aspect of Indian travel narratives that can yield rare theoretical insights into the construction of culture, language, ideology and subjectivity. Also the time frame of the study was not defined and the sole criterion was that the writer must be Indian. When we received an unprecedented number of abstracts we were overwhelmed with the choice and range of topics proposed and it was quite difficult to make the final selection. So one criterion for selection was to choose lesser known and regional texts, many of them written in the bhasha languages. The other was to focus on texts and issues that were more contemporary, ranging from train travels, texts written for children, travel blogs, and even cinematic narrations.

As the final contents list will show, the diversity of subjects is really mind-boggling. Divided into seven sections, the papers prove once again the protean nature of Indian travel narratives. The

(C) AesthetixMS 2020. This Open Access article is published under a Creative Commons Attribution Non-Commercial 4.o International License (http://creativecommons.org/licenses/by-nc/4.o/), which permits non-commercial re-use, distribution, and reproduction in any medium, provided the original work is properly cited. For citation use the DOI. For commercial re-use, please contact editor@rupkatha.com. 
'General Overviews' section contains three articles, two of which focus on Bengali secular travel culture and texts penned by women. The third article talks about the Bjojpuri speakers who went as girmitiyas to work in various British plantations in different colonies around the world. Six articles comprise the second section entitled 'Pilgrimages.' These include nineteenth century travels of Hindus to the holy city of Benaras as well as to various places in the Himalayas, including Kedarnath, Badrinath, Kailash and Mansarovar. The hajj pilgrimage to Mecca and the tourist potentials of the recently inaugurated corridor for Sikh pilgrims to visit Kartarpur Sahib in Pakistan have also been addressed in two different articles. Tibet and mountaineering issues have been discussed in three articles of the third section through various perspectives. One paper focuses on the transformative agency of the Nanda Devi on Bill Aitken, another analyses two literary texts by Vikram Seth and Nabaneeta Dev Sen that narrate their sojourns in Tibet. The continuous exchange of scholars and scholarly texts between India and Tibet over the centuries is the subject of another essay. Apart from documenting their journeys, we are told how the scholars initiated huge influx of literary texts between these two ancient countries, including the birth of Buddhist literature in Tibet.

The North East has always been a neglected domain geographically, politically and literarily for the average pan-Indian public residing in the plains. Five very interesting articles on the Northeast give us an overview of travel narratives in Assamese literature from the $18^{\text {th }}$ century onwards to the recently written Nandita Haksar's Across the Chicken Neck: Travels in Northeast India (2013) which shows how Haksar seeks to 'unmap' the Northeast by writing her experiences with the people and places of Northeast India. The fifth section is titled 'Travelling West.' Six articles discuss travels to Victorian England, Afghanistan, Russia and several places in Africa from different perspectives. While two of them discuss individual texts in details, others focus on different reasons for each person travelling to the west, be it for religion, education, business, politics, wanderlust, or otherwise. The sixth section is the longest and comprises of eleven articles that analyze individual travel texts in details and from different points of view. Some of the texts are old and quite canonical whereas others are very recent, written in this twenty-first century. The last two articles of this section offer interesting study of one author, Shivya Nath and complement each other in a particular way. While one article discusses her 2018 text The Shooting Star: A Girl, Her Backpack and the World as a journey of exploration and reconstruction of the feminine self, the other analyses the blogspots the author maintains under the same title. It shows how travel narratives are also changing their nature in this age of technological advancement and instant communication.

In a sense of yoking heterogeneous elements together, the last miscellaneous section comprising six articles is in a way the most interesting. Very few people were aware of Solon Karthak's Nepali travelogues till he was recently awarded the Sahitya Akademi prize for 2019 (in February this year) for an anthology of travel narratives he published way back in 2013. Also many readers don't know much about Bhakti Mathur's illustrated Amma, Take Me To... series for children or considered narrations of journeying through Indian trains to be part of travel texts worthy of study. Studying film texts by theorizing the experience of travel in a Malayalam film, North 24 Kaatham by Anil Radhakrishnan or studying the Goopy Bagha trilogy of children's films made by Satyajit Ray and his son Sandip Ray, from the postcolonial queer dimension just proves once again how studying Indian travel narratives know no bounds.

A final note is necessary before concluding this introduction. The contributors for this collection comprise of senior academicians as well as young research scholars in the field. So, one should not expect the standard of all the articles to be the same. But I earnestly hope that everyone will enjoy 
3 | Editorial Introduction: India and Travel Narratives

reading them as much as I have enjoyed editing them and ruminate on how 'India and Travel Narratives' can be read and analyzed from multifarious and endless perspectives.

Somdatta Mandal

Former Professor of English, Visva-Bharati, Santiniketan.Email: somdattam@gmail.com

3 June, 2020 